\title{
The first technical sequences in human evolution from East Gona, Afar region, Ethiopia
}

Henry de Lumley ${ }^{1,2}$, Deborah Barsky ${ }^{3,}$, Marie Hélène Moncel $^{2}$, Eudald Carbonell ${ }^{3}$, Dominique Cauche ${ }^{1,2}$, Vincenzo Celiberti ${ }^{4}$, Olivier Notter $^{2,5}$, David Pleurdeau ${ }^{2}$, Mi-Young Hong ${ }^{6}$ Michael J. Rogers ${ }^{7} \&$ Sileshi Semaw ${ }^{8}$

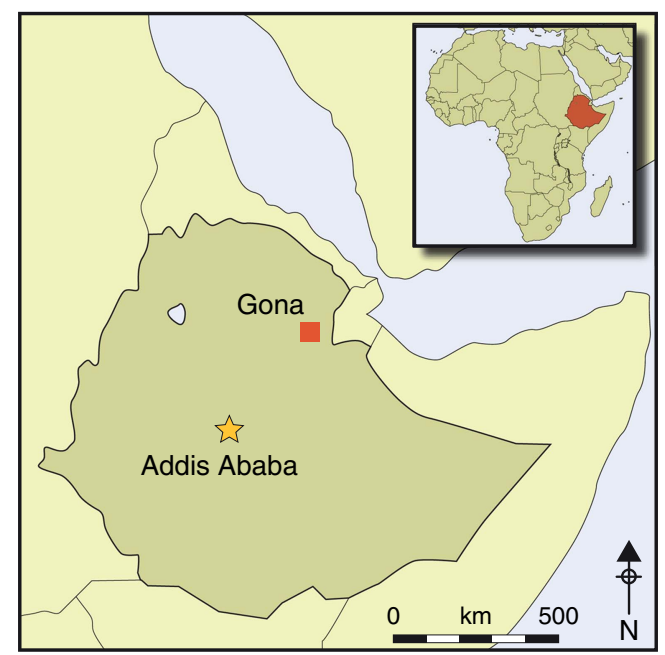

Gona in the Afar region of Ethiopia has yielded the earliest Oldowan stone tools in the world. Artefacts from the East Gona (EG) 10 site date back 2.6 million years. Analysis of the lithic assemblage from $E G 10$ reveals the earliest-known evidence for refitting and conjoining stone artefacts. This new information supplements data from other Oldowan sites in East Africa, and provides an important insight into the technological capacities and evolutionary development of hominins during this period.

Keywords: Ethiopia, East Gona, Oldowan, knapping, refitting

1 Institut de Paléontologie Humaine, 1, Rue René Panhard, 75013, Paris, France

2 Département Homme et Environnement, Muséum National d'Histoire Naturelle-Université de Perpignan Via Domitia-Sorbonne Universités, Institut de Paléontologie Humaine, France

3 Institut Català de Paleoecologia Humana i Evolució Social (IPHES), Zona Educacional 4, Campus Sescelades URV (Edifici W3), 43007 Tarragona, Spain

4 UPVD Université de Perpignan Via Domitia, UMR 7194 du CNRS MNHN Paris, Centre Européen de Recherches Préhistoriques de Tautavel, France

5 Musée d'Anthropologie préhistorique de Monaco, 56 Bis, Boulevard du Jardin Exotique, 98000, Monaco

6 Gyeore Institute of Cultural Heritage, 24 Muwon-ro, Deogyang-gu, Goyang-si, Gyeonggi-do, South Korea

7 Department of Anthropology, Southern Connecticut State University, 501 Crescent Street, New Haven, CT 06515-1355, USA

8 Centro Nacional de Investigación sobre la Evolución Humana, Paseo Sierra de Atapuerca, 3, 09002 Burgos, Spain

* Author for correspondence (Email: dbarsky@iphes.cat)

(C) Antiquity Publications Ltd ANTIQUITY 92365 (2018): 1151-1164 


\section{Introduction}

The Gona archaeological sites in the Afar region of Ethiopia have produced the earliestknown Oldowan stone tools. Excavated materials from the East Gona (EG) sites 10 and 12 and the Ounda Gona South (OGS) localities 6 and 7 are dated to 2.6-2.5 Ma (Semaw et al. 1997, 2003, 2009). Other Oldowan sites in East Africa have yielded toolkits with refitting lithic artefacts, which contribute significantly to our understanding of the earliest hominin stone-exploitation techniques, site integrity and post-depositional disturbance (Kroll \& Isaac 1984; de Lumley \& Beyene 2004; Delagnes \& Roche 2005; Schick \& Toth 2006; Goldman-Neuman \& Hovers 2009, 2011). Here we present conjoining and refitting sets identified in the EG 10 lithic assemblage during a Franco-Spanish-Ethiopian research mission in 2003. The assemblage includes six conjoining artefacts (three broken flakes and three knapping accidents) and seven knapping sets, one of which includes 14 flakes obtained from a single reduction sequence. Analysis of these sets confirms that the makers of the earliest Oldowan tools mastered knapping skills comparable with those documented at other, relatively younger Oldowan sites (Figure 1). These refitted sets help to define the technical capabilities of the Gona hominins - specifically in relation to their use of well-structured, sequential knapping techniques. Our results show how innovation within these simple but effective knapping strategies led early Oldowan hominins to produce formal variability in stone that provided evolutionary potential (Carbonell et al. 2009, 2016), and laid the foundation for technological development over the subsequent 2.5 million years.

The Busidima Formation-exposed along the Awash River in the Afar region of northeastern Ethiopia - provides a -3 Myr archive of climatic change and faunal and hominin evolution (Campisano 2012). In the 1970s, artefacts belonging to the earliest Oldowan were discovered on the banks of the Kada Gona, a tributary of the Awash River (Roche \& Tiercelin 1977, 1980; Johanson et al. 1980; Harris 1983). In 1992, a high density of artefacts was excavated from silty clay deposits at the EG 10 and 12 sites, some $300 \mathrm{~m}$ apart (Semaw et al. 1997; Semaw 2000). The EG stratigraphic sequence at both sites was accumulated within a floodplain context interspersed with volcanic tuffs, which permitted radiometric dating. The artefact-bearing deposits overlie a cobble conglomerate (intermediate cobble conglomerate, or ICC) - the apparent source of the raw materials used for the production of the Gona stone artefacts (Semaw et al. 1997, 2009). A tuff overlying the EG 10 site was dated by ${ }^{40} \mathrm{Ar} /{ }^{39} \mathrm{Ar}$ to $2.52 \pm 0.075 \mathrm{Ma}$. This corroborated the palaeomagnetic transition identified as the Gauss-Matuyama just stratigraphically below the sites with the same palaeomagnetic and similar ${ }^{40} \mathrm{Ar} /{ }^{39} \mathrm{Ar}$ dates also being repeated at the OGS 6 and 7 sites (Semaw et al. 1997, 2003, 2009).

While the EG deposits yielded no faunal remains, the OGS 6 and 7 excavations have provided comparable Oldowan stone tools associated with fragmentary fossil vertebrate remains. Several of these exhibit unambiguous hominin-induced modifications, including cut marks (Semaw et al. 2003; Dominguez-Rodrigo et al. 2005). Ongoing research and comparative analyses (e.g. tephrochronology and bioindicators) have established a coherent chronological framework for the entire sequence where these sites are located, and climatic and landscape reconstructions (Levin et al. 2004; Quade et al. 2004, 2008). With regard to the hominins responsible for making these tools, while Australopithecus garhi fossils of 


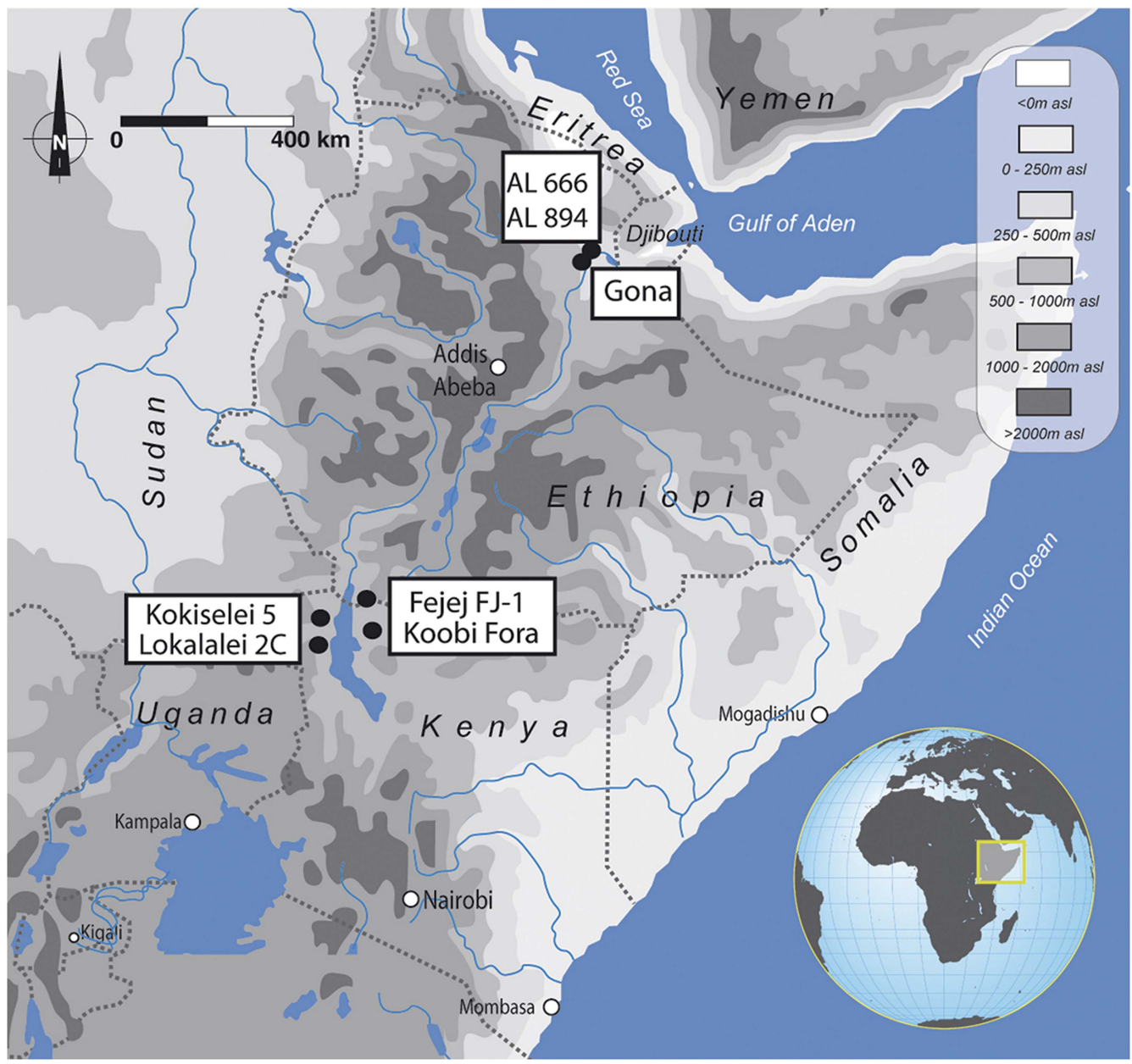

Figure 1. Map showing the locations of some early African Oldowan sites mentioned in the text that have yielded refitting lithic sets: A.L. 666 and 894 in the Makaamitalu Basin (Hadar region of Ethiopia); Fejej FJ-1a in the Omo-Turkana Basin of Ethiopia; Lokalalei $2 C$ and Kokiselei 5 in West Turkana, Kenya (figure by authors).

equivalent age to the EG and OGS sites have been excavated from the Hata Member of the Bouri Formation (Middle Awash) (Asfaw et al. 1999), a mandible from Ledi-Geraru in the Afar indicates that early Homo dates to $2.8 \mathrm{Ma}$ (Villmoare et al. 2015).

Discoveries made over the past 50 years in the East African Rift Valley have extended the timeframe and morpho-technological database of the earliest stone industries in Africa. Sites include: A.L. 666 and A.L. 894 in the Makaamitalu Basin in the Hadar region of Ethiopia; Omo 57 and 123, Member F of the Shungura Formation, Ethiopia; Fejej FJ-1a in the OmoTurkana Basin of Ethiopia and Kenya; and Lokalalei 2C in West Turkana, Kenya (Merrick et al. 1973; Corvinus 1975; Corvinus \& Roche 1976; Asfaw et al. 1991; Kimbel et al. 1996; Roche et al. 1999; Hovers et al. 2002; de la Torre 2004; de Lumley \& Beyene 2004; Delagnes \& Roche 2005; Boisserie et al. 2008; Goldman-Neuman \& Hovers 2009; Hovers 
2009, 2012). Some younger Oldowan localities, such as at Koobi Fora in East Turkana, and Kokiselei 5 in West Turkana (Nachukui Formation) (Bunn et al. 1980; Isaac \& Harris 1997; Texier et al. 2007), have also yielded refitting lithic sets that reveal Oldowan technical variability. Applied lithic research methodologies_-particularly the chaîne opératoire concept (Soressi \& Geneste 2011) — contribute to our understanding of these archaic industries. This procedural methodology analyses each phase in the production of lithic artefacts, and is better suited to the non-standardised character of Oldowan lithic assemblages than the classic, typebased methodology, which is burdened by the chronology-culture equivalence paradigm (Bordes 1961). The chaîne opératoire approach allots value to all components of a toolkit by regarding each element as a link in a chain of action or production. To understand each conceptual and physical phase of a reduction sequence, stone-tool analysis has diverged into distinct yet related fields of study (e.g. petrography and lithic sourcing, traceology, technology, spatial distribution), among which the refitting of artefacts is of foremost significance.

The importance of refitting lithic series in the earliest African assemblages was first recognised at Olduvai Gorge and Koobi Fora (Kroll \& Isaac 1984), where the refitting of lithic artefacts aided in the interpretation of site-formation processes. The value of refitting lithic sets-alongside the chaîne opératoire approach-for the understanding of early hominin flake-manufacture processes is further underlined by work on the Lokalalei 2C assemblage, dating to 2.3 Ma (Delagnes \& Roche 2005). Indeed, lithic assemblages with refitting items have been found in some of the oldest excavated sites with favourable preservation conditions.

\section{Conjoining and refitting lithic sets from EG 10}

The fresh appearance of the lithics at EG 10 and the numerous small flakes in the assemblage (889 flakes $<20 \mathrm{~mm}$ long; 38.4 per cent of the assemblage) indicate low post-depositional disturbance. Hominins at EG 10 preferentially knapped trachyte and rhyolite cobbles with a low phenocryst index, purposefully avoiding other rocks in the natural source conglomerate (Stout et al. 2005, 2010). That the hominins were carefully selecting their raw materials is also emphasised by differences in the ranges of cobble size and shape in the archaeological sample, compared with the source conglomerate (Stout \& Semaw 2006). Similar behavioural patterns are documented at other early Oldowan sites (de Lumley \& Beyene 2004; Goldman-Neuman \& Hovers 2009).

The EG 10 toolkit comprises predominantly small, non-standardised flakes without secondary modification (Figure 2). In agreement with Semaw (2000), Stout and Semaw (2006) and Semaw et al. (2009), our analysis shows most of the cores have been knapped unifacially (55.9 per cent), rather than bifacially (26.5 per cent) or multifacially (17.6 per cent). Some pieces with traces possibly attributable to use-wear on their worked edges were retained as cobble tools (13 items, 0.6 per cent of the assemblage). Irregular retouch or crush marks were observed on $<5$ per cent of flakes and were concentrated on sharp edges rather than flat contact areas (e.g. cortical surfaces or 'Siret fractures'-accidental knapping fractures parallel to a flake's knapping axis). Only two items, however, exhibit intentional retouch, although they do not adhere to any standard configuration. Cores at EG 10 are typically

(C) Antiquity Publications Ltd, 2018 


\begin{tabular}{l|c|c}
\multicolumn{1}{c|}{ Tool type } & $\mathrm{n} \%$ & $\%$ \\
\hline whole cobbles & - & - \\
\hline broken cobbles & 3 & 0.1 \\
\hline cobble tools & 13 & 0.6 \\
\hline cores & 21 & 0.9 \\
\hline flakes $(>2 \mathrm{~cm})$ & 790 & 34.1 \\
\hline small flakes $(<2 \mathrm{~cm})$ & 889 & 38.4 \\
\hline angular fragments & 598 & 25.8 \\
\hline retouched pieces & 2 & 0.1 \\
\hline \multicolumn{1}{c|}{ Total } & 2316 & $100 \%$ \\
\hline
\end{tabular}

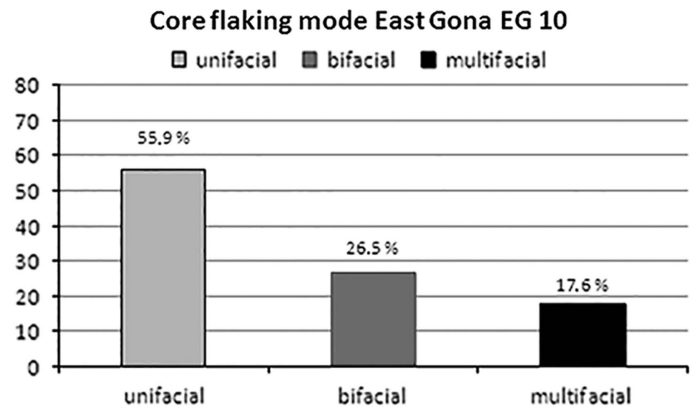

Figure 2. Left) number and relative frequency of stone tools categories from $E G$ 10; right) frequencies of different flaking modes are indicated combining cobble tools and cores (fgure by authors).

Oldowan and reflect generalised use of recurrent unifacial, unidirectional and orthogonal knapping strategies to produce flakes of different shapes, which often conserve residual cortex, particularly on the striking platforms (Semaw 2000; Stout et al. 2010). Meanwhile, variability of core forms at EG 10 appears to link directly to the physical and mechanical properties of the cobbles used, including quality, shape and the natural availability of flaking angles, as well as to the length (in terms of complexity or the number of removals) of the knapping episodes. Some abrupt-edged cores displaying opposed cortical platforms may have been knapped using the bipolar-on-anvil method, although this has yet to be clearly demonstrated.

Six conjoining (broken) and seven refitting (knapping products) lithic sets were identified in the EG 10 assemblage: three broken flakes, three flakes broken from knapping accidents and seven knapping flake sets (Table $S 1$ in the online supplementary material). The three broken conjoins comprise fragments of single broken flakes, and include five fragments of one flake (assembled size $=46 \times 76 \times 26 \mathrm{~mm}$ ) and another mid-transversally broken, thin, long flake (assembled size $=65 \times 48 \times 11 \mathrm{~mm}$ ). The other, relatively large conjoining flake also presents a mid-transverse fracture (assembled size $=82 \times 70 \times 26 \mathrm{~mm}$ ). The knapping accidents (three refits) are all of Siret type, composed of the two halves of split flakes. Most of these flakes present cortical platforms.

In total, the seven knapping sets comprise 41 knapped products out of 2316 artefacts (1.77 per cent of the assemblage). Six of the seven sets include only two refitting flakes, and one set consists of 14 refitted whole and broken flakes; all demonstrate a similar knapping strategy. Relatively long knapping episodes are evidenced by the high number of unidirectional convergent or centripetally oriented flake negatives on dorsal surfaces, as well as from a generally low degree of residual cortex. Apart from numerous cortical striking platforms, nearly a third of the flakes from the entire seven sets have cortical lateral and/or distal edges, revealing the exploitation of the natural surfaces of small cobbles. These refitted flake series reveal a knapping strategy involving recurrent blows from natural platforms opportunistically used to produce flakes in unidirectional series following the configuration of the cortical platforms. To continue producing flakes from cortical surfaces, the cobbles were rotated as knapping progressed. Flaking directions therefore followed the dictates of the original cobble shape. 

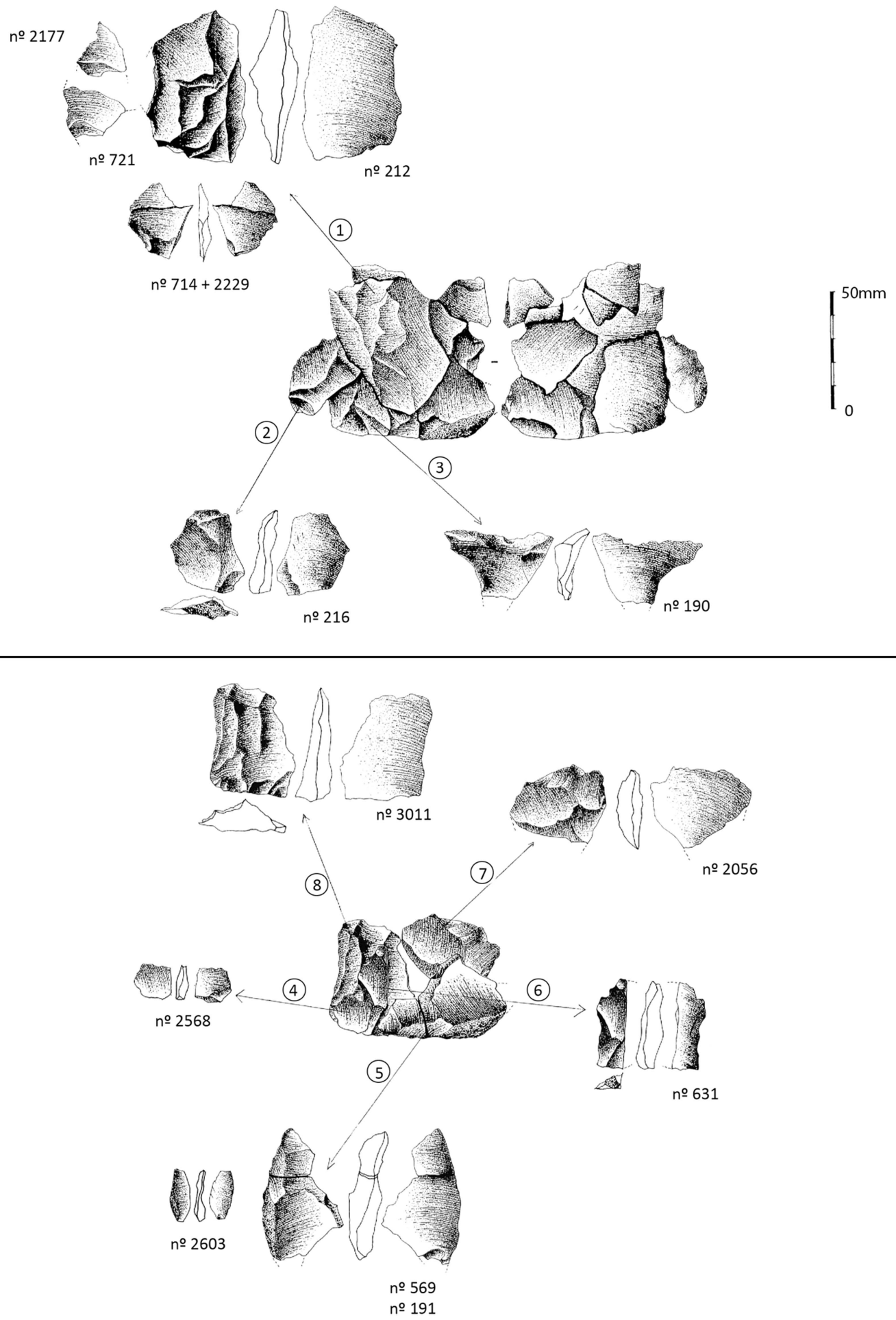

Figure 3. The largest knapping set from EG 10: the set of 14 items comprises trachyte whole and broken flakes. Above) dorsal and ventral views of the second flake series from the refitted set; below) dorsal and ventral views of the first flake series from the knapping set. Flake surface morphologies represent a sequential, unifacial, centripetal knapping strategy. Flakes have cortical or broken platforms (illustrations by D. Cauche).

(C) Antiquity Publications Ltd, 2018 
The first knapping set is composed of two broken flakes (oriented $34 \times 28 \mathrm{~mm}$ and $24 \times 30 \mathrm{~mm}$ ) sequentially knapped from the same cortical platform. The smaller of the two presents orthogonal dorsal scars. The second set is composed of two small flakes $(36 \times 20 \mathrm{~mm}$ and $31 \times 20 \mathrm{~mm}$ ) with unidirectional removal negatives (refitted flake $=$ five negatives). The third set comprises a larger flake $(49 \times 46 \mathrm{~mm})$ with six centripetal negatives. The distally refitted flake $(40 \times 24 \mathrm{~mm})$ preserves a large cortical area on its dorsal surface and has a proximal fracture. The fourth knapping set is composed of two refitted short flakes, unidirectionally knapped from a cortical platform $(31 \times 40 \mathrm{~mm}$ and $34 \times 38 \mathrm{~mm})$. On one of the flakes, the continuity between the cortical platform and the cortical lateral edge illustrates how the blows were delivered peripherally following the natural platform and the rounded shape of the cobble. Refitted, the flakes exhibit a dorsal surface with six removal negatives from three knapping directions as the cobble was turned to take advantage of its cortical surface. Another knapping set reveals the same strategy, in which a smaller flake $(33 \times 28 \mathrm{~mm})$ was knapped from a larger one with a lateral Siret break. The latter $(46 \times 26 \mathrm{~mm})$ presents a convex lateral edge with cortex corresponding to a small, rounded cobble. At least four removals are visible on the dorsal surface of this refitted set. The sixth knapping set assembles two unidirectionally produced flakes, whose features also reveal the same exploitation method using a peripheral cortical platform (assembled oriented size $=62 \times 37 \mathrm{~mm}$ ).

The most complete refitted set comprises 14 flakes and broken flakes (but no core) from a single knapping event. It clearly demonstrates a strategy wherein a recurrent gesture was employed to strike flakes from a cortical platform (average flake size $=39 \times 28 \times 10 \mathrm{~mm}$ ). The refitted knapping set reproduces the peripheral convex cortical edge of a mid-sized cobble that provided the privileged striking platform. Although incomplete, this knapping set represents a longer version of the same production strategy observed above. While the distribution of the negatives and the volumetric features of some cores do show bifacial or multifacial knapping strategies, the refits presented here illustrate clearly the mechanics of the dominant, unidirectional knapping strategies used at EG 10. These configurations confirm that hominins were performing the "chaining together of flake removals" (Stout et al. 2010: 480), using systematic, successive gestures, which reflect a planned action. Although not excessively complex, the technical gestures used at EG 10 reveal manual dexterity, precision and control in the manipulation of the cores. The refits described here further increase our knowledge about these chains of actions, demonstrating that the position of each successive removal in the reduction sequence was dictated predominantly by cobble shape, as hominins chose to maintain the use of smooth cortical (rather than prepared) striking platforms. The evidence suggests that the variability of cores, which defines the distinct earliest Oldowan core 'types' (e.g. unifacial uni- or bi-directional; unifacial centripetal), is largely affected by initial cobble shape-particularly when hominins produced flakes preferentially from cortical platforms (Carbonell et al. 2009; Stout et al. 2010).

Individual flakes and cores do not necessarily demonstrate the sequential nature of the dominant flake-extraction gesture, evidenced here by the refits from EG 10. While platform changes are generally recognised from multiple or converging negative orientations on flake dorsal surfaces and divergences of core forms, the EG 10 refits show that both of these characteristics can reflect initial cobble shape and the preferential use of cortical platforms.

(C) Antiquity Publications Ltd, 2018 


\section{The EG 10 refitted lithic sets in the context of the earliest Oldowan}

The EG 10 assemblage and refits can be compared with published data from other earliest African Oldowan sites, including Lokalelei 2C, A.L. 666 and 894, and Fejej FJ-1a (Figure 4). Contextual reconstructions of these sites confirm that artefacts were buried rapidly in fluvial or floodplain sediments, while the presence of small-sized lithic items $(<20 \mathrm{~mm}$ long $)$ and refitting sets indicate a low degree of post-depositional perturbation.

Lokalalei $2 \mathrm{C}$ has yielded a rich lithic assemblage with numerous refitting itemsincluding flakes and cores (Roche et al. 1999; Delagnes \& Roche 2005). As at EG 10, refits assembled from Lokalalei $2 \mathrm{C}$ illustrate the prevalent use of unifacial knapping strategies to produce unidirectional flakes, generally from cortical platforms. The Lokalalei $2 \mathrm{C}$ assemblage, however, differs from EG 10 in the incorporation of intentional breakage (e.g. split cobble) into the chaînes opératoires to create fracture planes with which to initiate knapping processes. At Lokalelei 2C, hominins systematically modified the knapping direction on cores, thus permitting longer knapping processes on single cores, and sometimes producing more invasive flakes (i.e. affecting larger surfaces of the cores). We therefore infer a more advanced planning stage for the knapping procedures at Lokalelei $2 \mathrm{C}$ than at EG 10, reflected in the high productivity of certain cores. This is attested by refitted lithic sets that include a large number of artefacts. With a similar chronology, A.L. 666 has yielded refitted lithic artefacts from an assemblage mainly comprised of flakes with cortical residue, plain platforms and unidirectional removal patterns on dorsal surfaces. Nearby A.L. 894 has yielded lithic refits in an assemblage composed of flakes and fragments, which include some cores and a few retouched items (Goldman-Neuman \& Hovers 2012).

The Fejej FJ-1a site has also provided an extensive set of refits (108 pieces comprising 38 refitted sets, or six per cent of the assemblage), with broken flakes (Siret or lateral fractures), successively knapped flake sets and core-flake sets (Asfaw et al. 1991; de Lumley \& Beyene 2004). The assemblage was knapped from cobbles sourced from a local conglomerate, and shows a strong predominance of quartz as the preferred raw material ( 91 per cent), followed by basalt and gneiss. Cores are mostly unifacially knapped (60 per cent), compared to bifacial (11 per cent) and multifacial (29 per cent) strategies (de Lumley \& Beyene 2004). Flakes and fragments generally display residual cortex, especially on striking surfaces (flake types IIII = 77.5 per cent) (Toth 1985; Barsky et al. 2011). At FJ-1a, where overall cobble size was smaller than at EG 10, peripheral removals were often made using a controlled bipolar-onanvil technique. Obtaining suitable knapping planes from the small rounded cobbles used at Fejej was occasionally achieved by surface preparation (Barsky et al. 2011: figs 7-8). Compared to EG 10, the Fejej FJ-1a assemblage and refits reflect a wider range of knapping strategies, including variants of controlled bipolar-on-anvil, bidirectional, orthogonal and multidirectional techniques (each removal providing a platform for the next with a core rotation following each blow).

These sites have yielded lithic assemblages with abundant and well-preserved knapping debris, including very small items, in a deltaic or flood-plain environment with a low level of post-depositional disturbance. Cores show features indicating the preferential use of unifacial knapping strategies. Across all sites, the end products indicate that cortical platforms were 

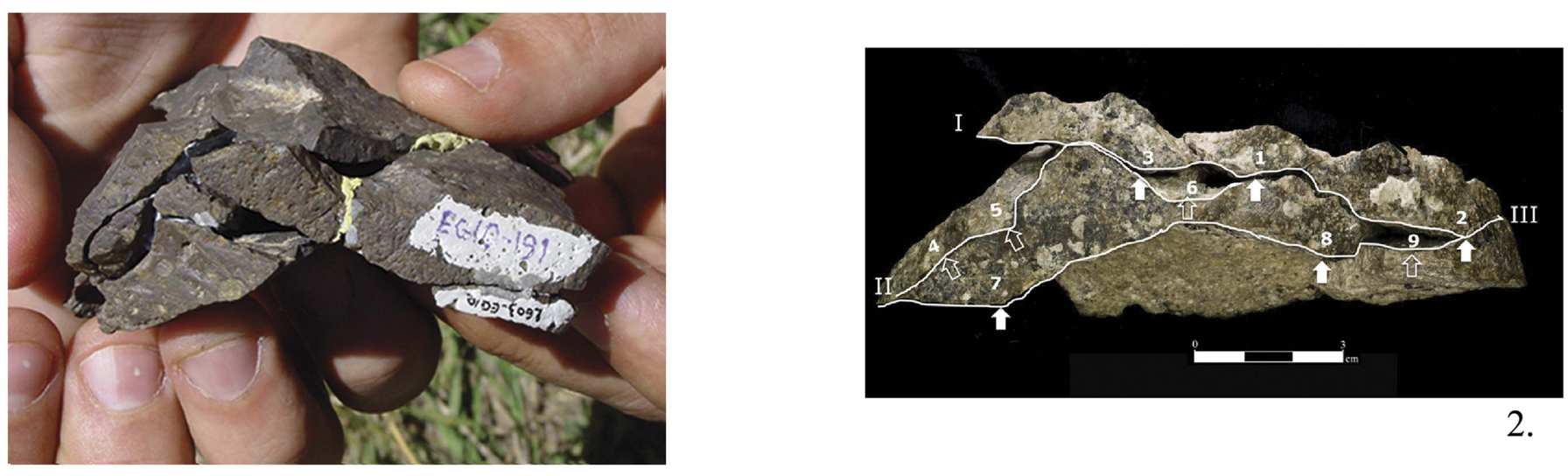

2.

1.

ज্

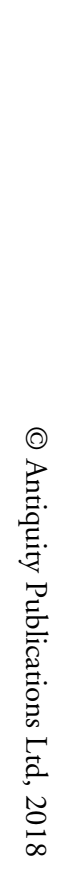

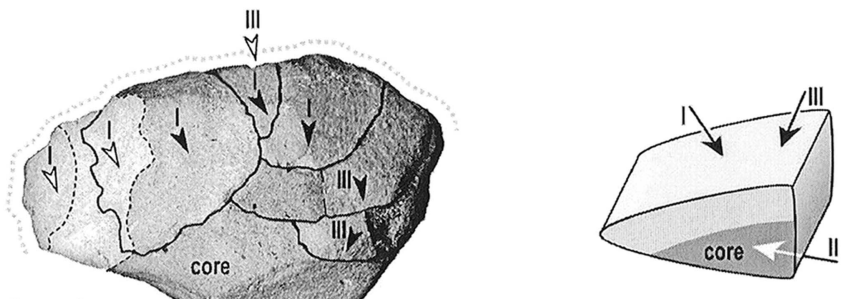

Face A

$30 \mathrm{~mm}$

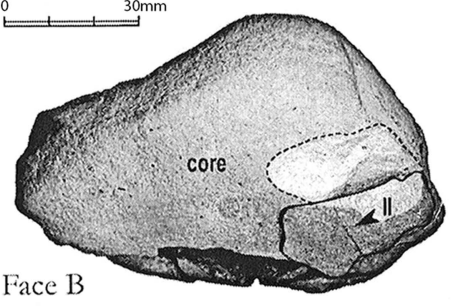

I, II, III ..

\begin{tabular}{|c|cc|c|c|}
\hline Series & $\begin{array}{r}\text { Refitted pieces } \\
\text { (framments) }\end{array}$ & Missing pieces & $\begin{array}{c}\text { Total of refitted } \\
\text { and missing pieces }\end{array}$ \\
\hline I & 3 & $(3)$ & 2 & 5 \\
II & 1 & $(1)$ & 0 & 1 \\
III & 2 & $(3)$ & 1 & 3 \\
core & 1 & $(1)$ & 0 & 1 \\
\hline TOTAL & 7 & $(8)$ & 3 & 10 \\
\hline
\end{tabular}

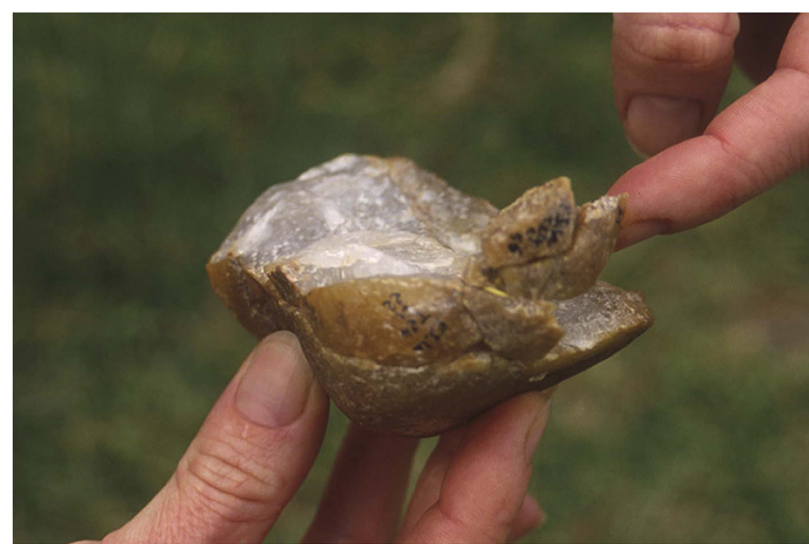

4.

direction of successive series of removals successive series of removals extension of suitable natural striking platforms 3 .

Figure 4. Refitting sets from earliest Oldowan sites illustrating the unifacial unidirectional knapping method, whereby flakes were knapped using recurrent blows from cortical cobble platforms: 1) East Gona 10 (2.6 Ma; photograph by D. Barsky); 2) A.L. 894, Hadar, Ethiopia (-2.35 Ma; Hovers 2012: 59); 3) Lokalelei 2C (2.34 Ma; Delagnes \& Roche (2005: 443)); 4) FJ-1a (1.96 Ma; photograph by D. Barsky).

\section{Research}


preferred for flake production. These toolkits are further characterised by selective patterns in the use of locally available raw materials, limited formal standardisation and the scarcity of small retouched tools on flakes and large cobble tools. These features generally define the earliest African Oldowan, and therefore do not appear to be determined by specific site contexts or raw material constraints alone. The subtle technical advances observed at Lokalelei 2C and Fejej FJ1-a, for example, indicate that hominins were expanding their technological capacities to overcome the constraints posed by initial cobble shape or recalcitrant raw materials. This supports the proposition by Carbonell et al. $(2009,2016)$ that additional stages within Oldowan variability demonstrate evolutionary potential.

\section{Conclusions}

Previous work in the Gona research area demonstrates that, very early on, hominins were systematically making tools from carefully selected raw materials, and that they had mastered schemes of controlled stone breakage (Semaw et al. 1997, 2009; Semaw 2000; Stout et al. 2005). The lithic sets from EG 10 represent a significant addition to the existing evidence base. Conjoining and refitting items from EG 10 include same-flake elements and knapping sets. One flake-only series with 14 refitting items illustrates how recurrence in unidirectional peripheral knapping from a cortical platform resulted in the unifacial centripetal strategy. Analogous knapping modes are described from other early Oldowan sites with refitted lithic sets, although all are younger than EG 10. Collectively, the Gona sites provide an exceptional opportunity to observe the gestural sequencing of hominins during the earliest stages of stone tool-making.

The conjoining and refitting lithic sets presented here from EG 10 provide complementary information concerning the first technical sequences in human evolution. They clearly illustrate the systematic percussion gestures characterised by—but not limited to - the recurrent unifacial and unidirectional knapping of cortical platforms. These data also show that many Oldowan core forms are reflective of original cobble shape, as well as the length of knapping episodes. Thus, at EG 10, cobbles were selected for their natural knapping angles. At Lokelelei $2 \mathrm{C}$ and Fejej FJ-1a, however, simple additions to the first stages in the reduction processes -including cobble breakage or preparatory removals to reveal suitable knapping platforms - were used as strategies to overcome constraints imposed by initial cobble shape. The refits from A.L. 894 and Lokalelei 2C show other developments in the unifacial recurrent unidirectional strategy, including offset removals and striking platform changes (Delagnes \& Roche 2005; Hovers 2012).

Such subtle differences in technical behaviours are vital to defining variability in the earliest Oldowan (Carbonell et al. 2009, 2016). Although lithic technologies remained virtually unchanged over a very long period $(2.6$ to $-2.0 \mathrm{Ma})$, there were some advances over time. In terms of diachronic similarities or differences (2.6 Ma at Gona, 2.3 Ma at Lokalalei and A.L. 894 and 1.96 Ma at Fejej), raw material acquisition patterns were selective in terms of both quality and shape. While EG 10 hominins exploited the natural knapping angles offered by cortical cobble surfaces, those at Lokalelei $2 \mathrm{C}$ and at FJ-1a sometimes incorporated basic methods of knapping surface preparation (e.g. split cobble; preparatory removals). Site-wide assemblage composition—principally knapping waste (flakes and cores) — changes little over this period, while cobble-tools at FJ-1a are differentiated more clearly

(C) Antiquity Publications Ltd, 2018 
from simple cores. Finally, while the dominance of unidirectional knapping strategies reflecting a relatively low degree of technological diversity was maintained throughout the early Oldowan, an increase in platform changes and multifacial knapping at some sites reflects a diversification in Oldowan technological strategies.

The refitting evidence presented here allows us to appreciate the dexterity of early Oldowan $(2.6 \mathrm{Ma})$ stone knappers, and confirms that they mastered systematic stoneknapping skills comparable with those observed at younger Oldowan sites $(>1.75 \mathrm{Ma})$. The earliest Oldowan therefore laid the foundations for later stone technologies, which only show significant change with the advent of the Acheulian techno-complex $-1.75 \mathrm{Ma}$ (Lepre et al. 2011; Beyene et al. 2013). Refitting from Kokiselei 5, for example, illustrates that, by 1.65 $\mathrm{Ma}$, hominins had attained higher levels of technical skill, involving more elaborate solutions to overcome the morphological constraints of the cobbles that they chose to knap (Texier et al. 2007). The refitted lithic sets presented here demonstrate clearly that hominins at EG 10 preferentially exploited natural extraction angles without creating new ones. Striking platforms were not prepared, and knapping directions were chosen in accordance with the availability of suitable angles, guiding negative crests and appropriate extraction surface convexities to enable production.

\section{Acknowledgements}

We thank the Authority for Research and Conservation of Cultural Heritage and the National Museum of Ethiopia for permission to study the East Gona material. The L.S.B. Leakey Foundation and the National Science Foundation provided funding. We are grateful to Yonas Beyene for his role in facilitating this study. We also wish to thank J.W.K. Harris for supervising the EG 10 and 12 excavations. We extend our gratitude to the Institut de Paléontologie Humaine and the Département de Préhistoire du Muséum National d'Histoire Naturelle, the Centre Européen de Recherches Préhistoriques in Tautavel, the Laboratoire Départemental de Préhistoire du Lazaret and to the Institut Català de Paleoecologia Humana i Evolució Social and Universitat Rovira i Virgili. The research of D.B. and E.C. has been funded by the Spanish government (CGL2016-80975-P and CGL2015-65387-C3-1-P).

\section{Supplementary material}

To view supplementary material for this article, please visit https://doi.org/10.15184/aqy.2018.169

\section{References}

Asfaw, B., Y. Beyene, S. Semaw, G. Suwa, T. White \& G. Wolde. 1991. Fejej: a new paleoanthropological research area in Ethiopia. Journal of Human Evolution 21: 137-43.

https://doi.org/10.1016/0047-2484(91) 90004-F

Asfaw, B., T. White, O. Lovejoy, B. Latimer, S. Simpson \& G. Suwa. 1999. Australopithecus garhi: a new species of early hominid from Ethiopia. Science 284: 629-35.

https://doi.org/10.1126/science.284.5414.629
Barsky, D., C. Chapon-Sao, J.J. Bahain, Y. Beyene, C. Cauche, E. Desclaux, H. de Lumley, M.A. de Lumley, F. Marchal, P.E. Moullé \& D. Pleurdeau. 2011. The early Oldowan stone tool assemblage from Fejej Fj-1a, Ethiopia. Journal of African Archaeology 9: 207-24. https://doi.org/10.3213/2191-5784-10196

Beyene, Y., S. Кatoh, G. WoldeGabriele, W.K Hart, K. Uto, M. Sudo, M. Kondo, M. Hyodo, P.R. Renne, G. Suwa \& B. Asfaw. 2013. The characteristics and chronology of the earliest Acheulean at Konso, Ethiopia. Proceedings of the National Academy of Sciences of the USA 110: 1584-91. https://doi.org/10.1073/pnas.1221285110 
Boisserie, J.R., F. Guy, A. Delagnes, L.J. Hlukso, F. Bibi, Y. Beyene \& C. Guillemot. 2008. New palaeoanthropological research in the PlioPleistocene Omo group, Lower Omo Valley, SNNPR (southern nations, nationalities and people regions), Ethiopia. Comptes Rendus Palevol 7: 429-39. https://doi.org/10.1016/j.crpv.2008.07.010

Bordes, F. 1961. Typologie du Paléolithique ancien et moyen. Bordeaux: Delmas.

Bunn, H., J.W.K. Harris, G. Isaac, Z. Kaufulu, E. Kroll, K. Schick, N. Toth \& A.K. BeHrensmeyer. 1980. FxJj50: an Early Pleistocene site in northern Kenya. World Archaeology 12: 109-36. https://doi.org/10.1080/00438243.1980.9979787

Campisano, C.J. 2012. Geological summary of the Busidima Formation (Plio-Pleistocene) at the Hadar paleoanthropological site, Afar Depression, Ethiopia. Journal of Human Evolution 62: 338-52. https://doi.org/10.1016/j.jhevol.2011.05.002

Carbonell, E., R. Sala, D. Barsky \& V. Celiberti. 2009. From homogeneity to multiplicity: a new approach to the study of archaic stone tools, in E. Hovers \& D. Braun (ed.) Interdisciplinary approaches to the Oldowan: 25-38. Dordrecht: Springer.

Carbonell, E., D. Barsky, R. Sala \& V. Celiberti. 2016. Structural continuity and technological change in Lower Pleistocene toolkits. Quaternary International 393: 6-18. https://doi.org/10.1016/j.quaint.2015.04.008

Convinus, G.K. 1975. Palaeolithic remains at the Hadar in the Afar region. Nature 256: 468-71. https://doi.org/10.1038/256468a0

Corvinus, G.K. \& H. Roche. 1976. La préhistoire dans la région de Hadar (bassin de l'Awash, Afar, Ethiopie): premiers résultats. L'Anthropologie 80: 315-24.

Delagnes, A. \& H. Roche. 2005. Late Pliocene hominid knapping skills: the case of Localalei 2C, west Turkana, Kenya. Journal of Human Evolution 48: 435-72. https://doi.org/10.1016/j.jhevol.2004.12.005

DE LA TORRE, I. 2004. Omo revisited: evaluating the technological skills of Pliocene hominids. Current Anthropology 45: 439-65. https://doi.org/10.1086/422079
De Lumley, H. \& Y. Beyene. 2004. Les sites préhistoriques de la région de Fejej, Sud-Omo, Ethiopie, dans leur contexte stratigraphique et paléontologique. Paris: Association pour la Diffusion de la Pensée Française.

Dominguez-Rodrigo, M., T.R. Pickering, S. Semaw \& M.J. Rogers. 2005. Cutmarked bones from Pliocene archaeological sites at Gona, Afar, Ethiopia: implications for the function of the world's oldest stone tools. Journal of Human Evolution 48: 109-21. https://doi.org/10.1016/j.jhevol.2004.09.004

Goldman-Neuman, T. \& E. Hovers. 2009. Methodological issues in the study of Oldowan raw material selectivity: insights from A.L. 894 (Afar, Ethiopia), in E. Hovers \& D. Braun (ed.) Interdisciplinary approaches to the Oldowan: 71-84. Dordrecht: Springer.

- 2011. Raw material selectivity in Late Pliocene Oldowan sites in the Makaamitalu Basin, Hadar, Ethiopia. Journal of Human Evolution 62: 353-66. https://doi.org/10.1016/j.jhevol.2011.05.006 Harris, J.W.K. 1983. Cultural beginnings: PlioPleistocene archaeological occurrences from the Afar, Ethiopia. African Archaeology Review 1: 3-31. https://doi.org/10.1007/BF01116770

Hovers, E. 2009. Learning from mistakes: accidents and knapping skills in the assemblage of A.L. 894 (Hadar, Ethiopia), in K. Schick \& N. Toth (ed.) The cutting edge: new approaches to the archaeology of human origins: $137-50$. Bloomington (IN): Stone Age Institute.

- 2012. Invention, reinvention and innovation: makings of Oldowan lithic technology. Developments in Quaternary Science 16: 51-68. https://doi.org/10.1016/B978-0-444-538215.00005-1

Hovers, E., K. Schollmeyer, T. Goldman, G. Eck, K. Reed, D. Johanson \& W. Kimbel. 2002. Late Pliocene archaeological sites in Hadar, Ethiopia. Paper read in the meeting of the Paleoanthropology Society, Denver Colorado, March 2002. Journal of Human Evolution 42 (3): A17.

ISAAC, G.L. \& J. HARRIs. 1997. The stone artifact assemblages: a comparative study, in G. Isaac \& B. Isaac (ed.) Koobi Fora Research Project 5: 262-362. Oxford: Clarendon.

Johanson, D.C., M. Taieb, Y. Coppens \& H. Roche. 1980. New discoveries of Pliocene

(C) Antiquity Publications Ltd, 2018 


\section{The first technical sequences in human evolution from East Gona, Afar region, Ethiopia}

hominins and artifacts in Hadar: International Afar Research Expedition to Ethiopia (fourth and fifth seasons, 1975-1977). Journal of Human Evolution 9: 583-85.

https://doi.org/10.1016/0047-2484(80) 90085-8

Kimbel, W.H., R.C. Walter, D.C. Johanson, K.E. Reed, J.L. Aronson, Z. Assefa, C.W. Marean, G.G. Eck, R. Bobe, E. Hovers, Y. Rak, C. Vondra, T. Yemane, D. York, Y. Chen, N.M. Evensen \& P.E. Smith. 1996. Late Pliocene Homo and Oldowan tools from the Hadar Formation (Kadar Hadar Member), Ethiopia. Journal of Human Evolution 31: 549-61. https://doi.org/10.1006/jhev.1996.0079

Kroll, E.M. \& G.L. IsaAc. 1984. Configurations of artifacts and bones at Early Pleistocene sites in East Africa, in H.J. Hietala (ed.) Intrasite spatial analysis in archaeology: 4-31. Cambridge: Cambridge University Press.

Lepre, C.J., H. Roche, D.V. Kent, S. Harmand, R.L. Quinn, J.-P. Brugal, P.-J. Texier, A. Lenoble \& C.S. Feibel. 2011. An earlier origin for the Acheulian. Nature 477: 82-85. https://doi.org/10.1038/nature10372

Levin, N.E., J. Quade, S.W. Simpson, S. Semaw \& M. Rogers. 2004. Isotopic evidence for PlioPleistocene environmental change at Gona, Ethiopia. Earth and Planetary Science Letters 219: 93-100.

https://doi.org/10.1016/S0012-821X(03) 00707-6

Merrick, H.V., J. de Heinzelin, P. Haesaerts \& F.C. Howell. 1973. Archaeological occurrences of Early Pleistocene Age from the Shungura Formation, Lower Omo Valley, Ethiopia. Nature 242: 572-75.

https://doi.org/10.1038/242572a0

Quade, S.W., N. Levin, S. Semaw, D. Stout, P. Renne, M. Rogers \& S.W. Simpson. 2004. Paleoenvironments of the earliest stone toolmakers, Gona, Ethiopia. Geological Society of America Bulletin 116: 1529-44. https://doi.org/10.1130/B25358.1

Quade, J., N.E. Levin, S.W. Simpson, R. Butler, W.C. McIntosh, S. Semaw, L. Kleinsasser, G. Dupont-Nivet, P. Renne \& N. Dunbar. 2008. The geology of Gona, Afar, Ethiopia. The Geological Society of America Special Paper 446: 1-31.
Roche, H. \& J.J. Tiercelin. 1977. Découverte d'une industrie lithique ancienne in situ dans la Formation d'Hadar, Afar Central, Éthiopie. Comptes rendus de l'Académie des Sciences 284: 174-87.

- 1980. Industries lithiques de la Formation Plio-Pléistocène d'Hadar Éthiopie: campagne 1976, in R.E.F. Leakey \& B.A. Ogot (ed.) Proceedings of the VII ${ }^{\text {th }}$ Pan African Congress of Prehistory and Quaternary Studies: 194-99. Nairobi: The International Louis Leakey Memorial Institute for African Prehistory.

Roche, H., A. Delagnes, J.P. Brugal, C. Feibel, M. Kibunjia, V. Mourre \& P.J. Texier. 1999. Early hominid stone tool production and technical skill 2.34 Myr ago in West Turkana, Kenya. Nature 399: 57-60. https://doi.org/10.1038/19959

Sсніск, K. \& N. Tотн. 2006. An overview of the Oldowan industrial complex: the sites and the nature of their evidence, in K. Schick \& N. Toth (ed.) The Oldowan: case studies into the earliest Stone Age: 3-42. Bloomington (IN): Stone Age Institute.

Semaw, S. 2000. The world's oldest stone artefacts from Gona, Ethiopia: their implications for understanding stone technology and patterns of human evolution between 2.6-1.5 million years ago. Journal of Archaeological Science 27: 1197-214. https://doi.org/10.1006/jasc.1999.0592

Semaw, S., P. Renne, J.W.K. Harris, C.S. Feibel, R.L. Bernor, N. Fesseha \& K. Mowbray. 1997. 2.5-million-year-old stone tools from Gona, Ethiopia. Nature 385: 333-36. https://doi.org/10.1038/385333a0

Semaw, S., M.J. Rogers, J. Quade, P.R. Renne, R.F. Butler, M. Dominguez-Rodrigo, D. Stout, W.S. Hart, T. Pickering \& S.W. Simpson. 2003. 2.6-million-year-old stone tools and associated bones from OGS-6 and OGS-7, Gona, Afar, Ethiopia. Journal of Human Evolution 45: 169-77. https://doi.org/10.1016/S0047-2484(03)00093-9

Semaw, S., M.J. Rogers \& D. Stout. 2009. Insights into Late Pliocene lithic assemblage variability: the East Gona and Ounda Gona south Oldowan archaeology (2.6 million years Ago), Afar, Ethiopia, in K. Schick \& N. Toth (ed.) The cutting edge: new approaches to the archaeology of human origins: $211-46$. Bloomington (IN): Stone Age Institute. 
Soressi, M. \& J.M. Geneste. 2011. Special issue: reduction sequence, chaîne opératoire, and other methods: the epistemologies of different approaches to lithic analysis. PaleoAnthropology 2011: 334-50.

Stout, D. \& S. Semaw. 2006. Knapping skill of the earliest stone toolmakers: insights from the study of modern human novices, in N. Toth \& K. Schick (ed.) The Oldowan: case studies into the earliest Stone Age: 307-20. Bloomington (IN): Stone Age Institute.

Stout, D., J. Quade, S. Semaw, M.J. Rogers \& N.E. Levin. 2005. Raw material selectivity of the earliest stone toolmakers at Gona, Afar, Ethiopia. Journal of Human Evolution 48: 365-80.

https://doi.org/10.1016/j.jhevol.2004.10.006

Stout, D., S. Semaw, M.J. Rogers \& D. Cauche. 2010. Technological variation in the earliest Oldowan from Gona, Afar, Ethiopia. Journal of Human Evolution 58: 474-91.

https://doi.org/10.1016/j.jhevol.2010.02.005
Texier, P.J., H. Roche \& S. Harmand. 2007. Kokiselei 5, formation de Nachukui, west Turkana (Kenya): un témoignage de la variabilité ou de l'évolution des comportements techniques au Pléistocène ancien?, in P. Maret, E. Cornelissen \& I. Ribot (ed.) Section 15: préhistoire en Afrique: sessions générales et posters (British Archaeological Reports International series 1522): 11-22. Oxford: Archaeopress.

Тотн, N. 1985. The Oldowan reassessed: a close look at early stone artifacts. Journal of Archaeological Science 12: 101-20. https://doi.org/10.1016/0305-4403(85)90056-1

Villmoare, B., W.H. Kimbel, C. Seyoum, C.J. Campisano, E. DiMaggio, J. Rowan, D.J. Braun, J.R. Arrowsmith \& K.E. Reed. 2015. Early Homo at $2.8 \mathrm{Ma}$ from Ledi-Geraru, Afar, Ethiopia. Science 347: 1352-55. https://doi.org/10.1126/science.aaa1343

Received: 20 September 2017; Revised: 16 March 2018; Accepted: 27 April 2018 